\title{
Geochemistry of Mafic Magmas in the Hurricane Volcanic Field, Utah: Implications for Small- and Large-Scale Chemical Variability of the Lithospheric Mantle
}

\author{
Eugene I. Smith, Alexander Sánchez, J. Douglas Walker, ${ }^{1}$ and Kefa Wang ${ }^{1}$ \\ Center for Volcanic and Tectonic Studies, Department of Geoscience, University of Nevada, \\ Las Vegas, Nevada 89154-4010, U.S.A. \\ (e-mail: gsmith@ccmail.nevada.edu)
}

\begin{abstract}
A B S T R A C T
Low-silica basanite, basanite, and alkali basalt lava flows and cinder cones make up the late Quaternary Hurricane volcanic field (HVF) in the Colorado Plateau/Basin and Range transition zone of southwestern Utah. Strombolianand Hawaiian-style eruptions produced thin $(10 \mathrm{~m})$ a'a lava flows and 10 cinder and scoria cones that group geographically into five clusters. The five clusters can be further divided into four isotopic magma types that vary in ${ }^{87} \mathrm{Sr} /{ }^{86} \mathrm{Sr}$ from 0.7035 to $0.7049, \epsilon_{\mathrm{Nd}}$ from 1.6 to -7.5 , and ${ }^{206} \mathrm{~Pb} /{ }^{204} \mathrm{~Pb}$ from 17.4 to 18.7. Except for the Radio Towers and Volcano Mountain cone clusters, each volcano had a different parent magma and evolved by fractional crystallization of different amounts and proportions of olivine and clinopyroxene. Parent magmas of each isotope group formed by $0.5 \%-7 \%$ partial melting of lithospheric mantle composed of fertile lherzolite varying in garnet content from 1 to $4 \mathrm{wt} \%$. New ${ }^{40} \mathrm{Ar} /{ }^{39} \mathrm{Ar}$ dates indicate that the HVF formed over a period of at least $100 \mathrm{ka}$ during the late Quaternary. Along a transect from the Basin and Range to the Colorado Plateau, the source for Pliocene-late Quaternary alkali basalt magmas changes from asthenosphere in the Basin and Range to lithospheric mantle on the Colorado Plateau. The melting of a heterogeneous lithospheric mantle is the most viable mechanism for producing the observed chemical variability in the transition zone-Colorado Plateau part of the transect. Furthermore, chemical differences across the transect may reflect a major lithospheric boundary originally defined on the basis of $\mathrm{Nd}$ and $\mathrm{Pb}$ isotopes that is older and perhaps more fundamental than the present structural and physiographic boundary between the Basin and Range and Colorado Plateau.
\end{abstract}

\section{Introduction}

Geochemical studies of Tertiary to recent mafic volcanoes over the past $25 \mathrm{yr}$ have mainly focused on large volume eruptions that occur on ocean islands, in flood basalt provinces, and on or near oceanic spreading centers. Few have concentrated on low-volume continental cinder cones and related flows. In western North America a much larger effort has been expended to understand regionwide chemical and isotopic patterns of Pliocene and Quaternary mafic volcanism than to study individual small-volume fields or volcanoes. Nevertheless, those few studies of individual cinder cones and related flows showed that lavas and pyroclastic products can be chemically complex (e.g., Wilcox 1999.

Manuscript received August 27, 1998; accepted March 16,

${ }^{1}$ Isotope Geochemistry Laboratory, Department of Geology, University of Kansas, Lawrence, Kansas 66045, U.S.A.
1954; Luhr and Carmichael 1985; McBirney et al. 1987; Bradshaw and Smith 1994; Perry and Straub 1996).

This article represents a continuation of our work to understand the petrogenesis of small-volume volcanic systems (e.g., Feuerbach et al. 1993; Bradshaw and Smith 1994; Yogodzinski et al. 1996). It addresses the petrogenesis of mafic lavas of the Hurricane volcanic field in the transition zone between the Colorado Plateau and the Basin and Range province (fig. 1). Our study focuses on several cone clusters within the field to identify chemical differences between closely spaced volcanoes, chemical complexity of individual volcanic centers, and changes in chemistry with time. Our goals are to determine the processes that control compositional variation in small-volume mafic centers and to detect changes in the composition of mantle

[The Journal of Geology, 1999, volume 107, p. 433-448] @ 1999 by The University of Chicago. All rights reserved. 0022-1376/1999/10704-0004\$01.00 


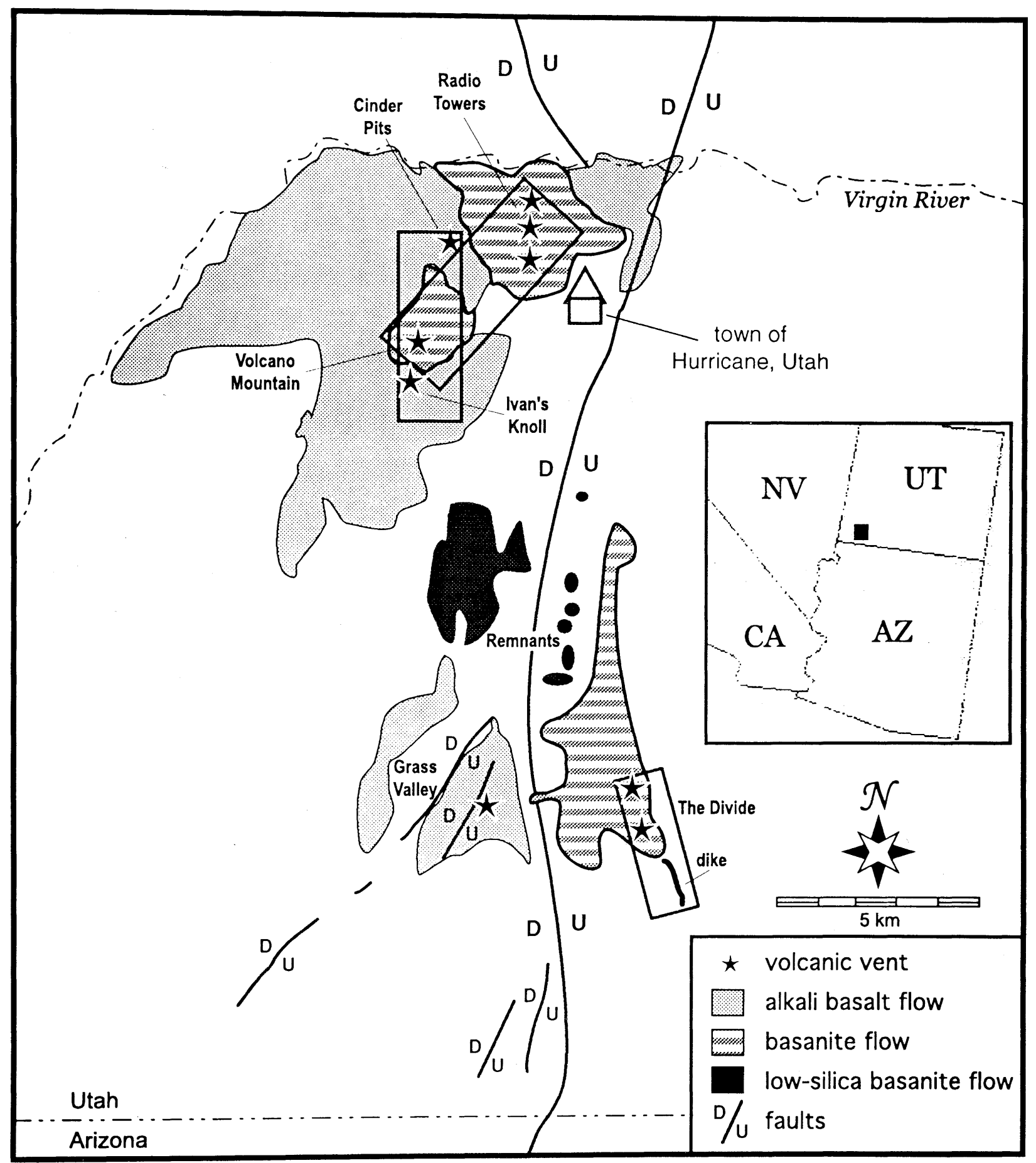

Figure 1. The Hurricane volcanic field is composed of five cone clusters outlined by rectangles: Cinder Pits, Radio Towers, Volcano Mountain-Ivan's Knoll, Grass Valley, and the Divide. 
sources beneath the Colorado Plateau/Basin and Range transition zone.

\section{Cinder Cone Clusters and Geochronology}

Ten cinder cones and associated flows make up the Hurricane volcanic field (fig. 1). Cinder cones range in size from $200 \mathrm{~m} \times 1 \mathrm{~km}$ (height $\times$ base diameter) at Volcano Mountain to $75 \mathrm{~m} \times 300 \mathrm{~m}$ (height $\times$ base diameter) at Ivan's Knoll. The 10 cinder cones group geographically into five clusters with a minimum total volume of about $0.5 \mathrm{~km}^{3}$ (fig. 1); volumes of individual cinder cone clusters range from 0.05 to $0.30 \mathrm{~km}^{3}$. Cones consist of bedded vesicular lapilli, bombs, and blocks. Aerodynamically shaped bombs (up to $2 \mathrm{~m}$ ) and welded spatter (agglutinate) form massive to bedded deposits that dip outward (away from the summit crater) on the flanks and dip inward (toward the summit crater) near the summits of the cones. Agglutinate consists of ribbon bombs and rootless flows. Lava lakes represented by thinly bedded basalt flows and agglutinate $(2-5$-cm-thick beds with a total thickness of 3-5 m) occur on the summit of Ivan's Knoll, a cone in the Cinder Pits cone cluster, and on the Grass Valley cone (fig. 1). The Volcano Mountain cone cluster contains two cones, Volcano Mountain and Ivan's Knoll. Lava flows are thin $(10 \mathrm{~m})$, mainly a'a, and vary in length from 1 to $7 \mathrm{~km}$. A lava flow $\left(353 \pm 45 \mathrm{ka},{ }^{40} \mathrm{Ar} /{ }^{39} \mathrm{Ar}\right.$ isochron date; fig. $2 \mathrm{~A}$ ) chemically and isotopically correlated to Ivan's Knoll underlies the town of Hurricane and is offset by the Hurricane fault. This flow was previously dated by Damon (cited by Best et al. 1980) at $289 \pm 86 \mathrm{ka}$ (K/Ar). The youngest flows from Volcano Mountain $\left(258 \pm 24 \mathrm{ka},{ }^{40} \mathrm{Ar} /\right.$ ${ }^{39} \mathrm{Ar}$ isochron date; fig. $2 B$; table 1 ; table 1 , along with tables $5-8$, is available from The Journal of Geology free of charge upon request) breached the northeast flank of the cone. We attempted to date the youngest event in this cone cluster by analyzing a sample from an aerodynamically shaped bomb at the summit of Volcano Mountain. The age spectrum for this sample has a saddle shape (fig. 2C). The lowest step has an apparent age of $270 \pm 50$ ka (fig. 2C). The isochron date for steps $1-8$ is $129 \pm 60 \mathrm{ka}$ with an ${ }^{40} \mathrm{Ar} /{ }^{39} \mathrm{Ar}$ of $301.5 \pm 2.4(2 \sigma$; fig. $2 C$ ). All that can be concluded from these data is that the maximum age of this sample is $270 \pm$ $50 \mathrm{ka}$. Although there is some uncertainty, geomorphic and geochronologic information indicate that volcanism continued for $10^{4}-10^{5} \mathrm{yr}$ at the Volcano Mountain cone cluster. Table 2 summarizes geomorphic features and ages for cone clusters of the Hurricane field. The table also compares Ham-

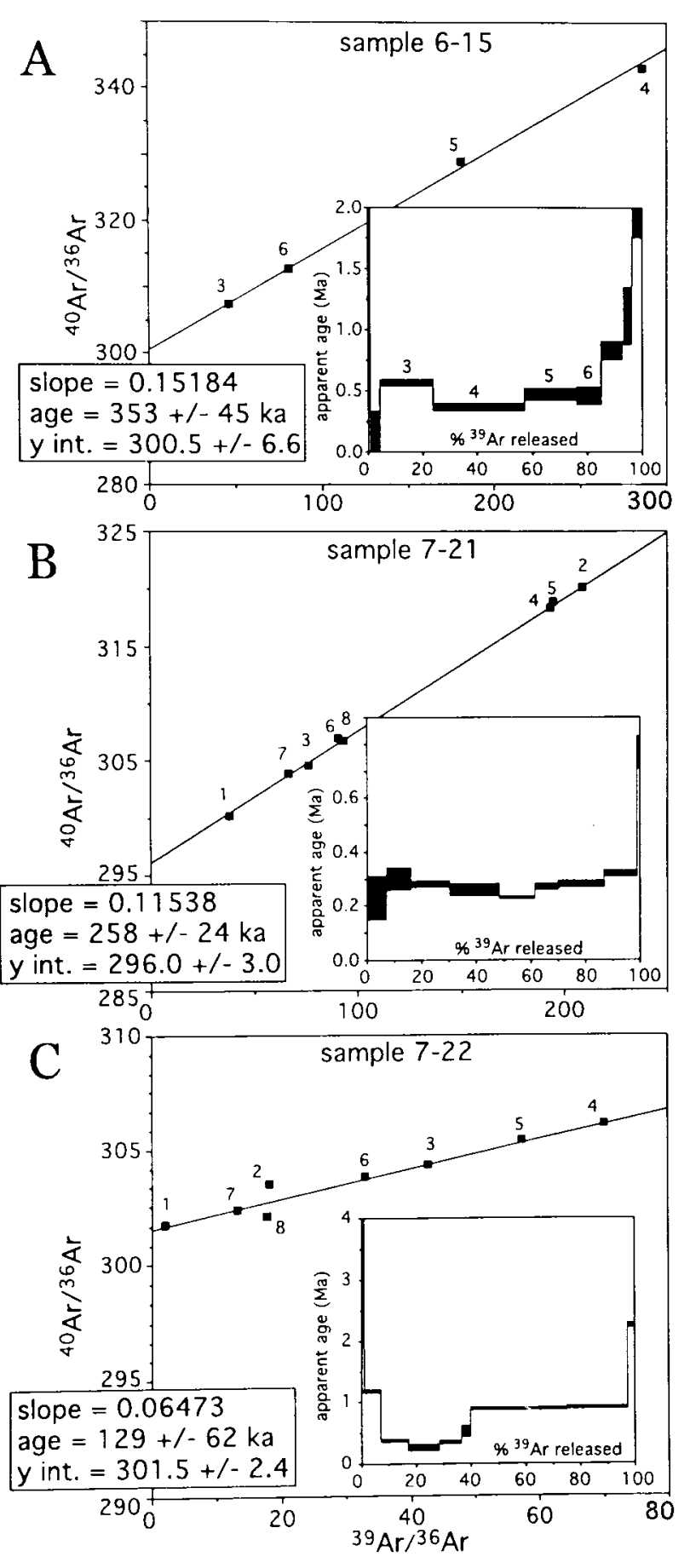

Figure 2. Age spectra and isochron plots for three samples from the Volcano Mountain-Ivan's Knoll cone cluster. $A$, Sample 6-15 is a flow just east of Hurricane, Utah, correlated to Ivan's Knoll. Samples 7-21 (B) and 7-22 (C) are from a flow and bomb, respectively, from the Volcano Mountain cone. 
Table 2. Summary of Geochronology and Cinder Cone Morphology in the Hurricane Area

\begin{tabular}{|c|c|c|c|}
\hline $\begin{array}{l}\text { Hamblin's } \\
\text { stage }\end{array}$ & Location & Geomorphic features & Age (ka) \\
\hline $2 a$ & Remnants & $\begin{array}{l}\text { Vent eroded away; flows eroded into } \\
\text { segments }\end{array}$ & \\
\hline $2 b$ & $\begin{array}{l}\text { Ivan's Knoll; flow that underlies } \\
\text { Hurricane Valley }\end{array}$ & Scoria eroded away; flow margins eroded & $353 \pm 45($ flow $)$ \\
\hline 3 & Volcano Mountain/Ivan's Knoll & Flows are not segmented by erosion & \\
\hline $3 a, b$ & Grass Valley & Flows are not segmented by erosion & \\
\hline $4 a$ & $\begin{array}{l}\text { Volcano Mountain; Cinder Pits; } \\
\text { Radio Towers }\end{array}$ & $\begin{array}{l}\text { Cones have vertical rills; flows close to } \\
\text { original shape }\end{array}$ & \\
\hline $4 b$ & $\begin{array}{l}\text { Upper Volcano Mountain flow; the } \\
\text { Divide }\end{array}$ & $\begin{array}{l}\text { Fresh surface morphology; flow margins } \\
\text { intact }\end{array}$ & $\begin{array}{l}258 \pm 24 \text { (Vol- } \\
\text { cano Moun- } \\
\text { tain flow) }\end{array}$ \\
\hline
\end{tabular}

blin's (1970) geomorphic stage classification, commonly used in the western Colorado Plateau area, with geomorphology and absolute age.

\section{Geochemistry}

Geochemistry and Petrography of Mafic Rocks of the Hurricane Volcanic Field. Olivine phenocrysts dominate in volcanic rocks from the Hurricane volcanic field and rarely make up $>10 \%-25 \%$ of the rock volume. Phenocrysts vary from equant $1 \mathrm{~mm}$ euhedral grains to $3 \mathrm{~mm} \times 6 \mathrm{~mm}$ laths. Spinel occurs in the matrix and as small inclusions in olivine. Iddingsite rims on olivine are common in the flows from the Remnants and can also be found on some olivine phenocrysts from Ivan's Knoll and associated flows. Less common $(<5 \%)$ are phenocrysts of clinopyroxene that are rods $1 \mathrm{~mm}$ or less in length. Phenocrysts of $1-2 \mathrm{~mm}$ clinopyroxene $(15 \%), 1 \mathrm{~mm}$ hornblende $(<5 \%)$, and $2 \mathrm{~mm}$ olivine $(25 \%)$ occur in two dikes at the Divide cluster.

Low-silica basanites, basanites, and alkali basalts make up the Hurricane volcanic field (fig. 3). Lowsilica basanites range between $41.5 \%$ and $42.1 \%$ $\mathrm{SiO}_{2} ; \mathrm{MgO}$ and $\mathrm{CaO}$ average $13.6 \%$ and $12.5 \%$, respectively; and $\mathrm{TiO}_{2},<1.9 \%$. Magnesium numbers average 69.7 , a value that is close to the magnesium number of 71 for primary mantle-derived basalts (e.g., Green et al. 1974; tables 3, 4, and 5). Basanites range in $\mathrm{SiO}_{2}$ from $43.2 \%$ to $46 \% ; \mathrm{MgO}$ averages $11.7 \%, \mathrm{CaO} 10.6 \%$, and $\mathrm{TiO}_{2}>2.25 \%$. Magnesium numbers vary from 59.6 to 68.7 and average 63.9 . Alkali basalt has $\mathrm{SiO}_{2}$ ranging from $46 \%$ to $51.6 \%$, $\mathrm{MgO}$ averages $7.5 \%, \mathrm{CaO} 9.5 \%$, and $\mathrm{TiO}_{2}<1.9 \%$. Magnesium numbers for this group vary from 49.6 to 62.8 and form a bimodal distribution with modes at 61 and 54.8. Low-silica basanites and basanites are nepheline normative (ne $=15-18$ and $5-12$, re- spectively). Only alkali basalts are both nepheline and hypersthene normative (fig. $3 B$ ).

The incompatible elements $\mathrm{Ba}, \mathrm{Sr}, \mathrm{Th}$, and $\mathrm{Nb}$ decrease as $\mathrm{SiO}_{2}$ wt \% increases when considering all rock types (fig. 4). For example, low-silica basanites $\left(\mathrm{SiO}_{2}\right.$ at $\left.42 \mathrm{wt} \%\right)$ contain about $80 \mathrm{ppm} \mathrm{Nb}$ and alkali basalts $\left(\mathrm{SiO}_{2}\right.$ at $\left.48-50 \mathrm{wt} \%\right)$ have $10-30$ ppm Nb. Normalized to ocean island basalt (OIB; Fitton et al. 1991), all rock types from Hurricane are enriched in large-ion lithophile (LIL) and light rare-earth elements (LREE), relative to the high field strength elements (HFSE) and the heavy rareearth elements (HREE; fig. 5). The only elements that show significant depletion when compared to $\mathrm{OIB}$ are $\mathrm{Rb}$ and $\mathrm{Nb}$ for all rock types, plus $\mathrm{K}$ for low-silica basanite. Although there is significant variation between major rock groups, incompatible element concentrations within groups are constant or show small increases in abundance with increasing $\mathrm{SiO}_{2}$. For example, while $\mathrm{Ni}$ changes by over 400 ppm in the basanites, $\mathrm{Zr}$ varies by $<100 \mathrm{ppm}$ and $\mathrm{Nd}$ by $<20$ ppm.

Hurricane basalts have ${ }^{143} \mathrm{Nd} /{ }^{144} \mathrm{Nd}$ ratios that vary from 0.512253 to $0.512718\left(\epsilon_{\mathrm{Nd}}=-7.5\right.$ to 1.6$)$, while ${ }^{87} \mathrm{Sr} /{ }^{86} \mathrm{Sr}$ ranges from 0.703678 to 0.704882 (fig. 6A). For clarity, in the remainder of this article, the magmas that the volcanic rocks represent are divided into four isotopic magma types (tables 3, 4, and 6). The basanites make up magma type $A$ and have ${ }^{87} \mathrm{Sr} /{ }^{86} \mathrm{Sr}=0.7040-0.7043, \epsilon_{\mathrm{Nd}}=-0.2$ to -1.8 , and ${ }^{206} \mathrm{~Pb} /{ }^{204} \mathrm{~Pb}$ ca. 18.35 . Basanites from Volcano Mountain have a narrower range of ${ }^{87} \mathrm{Sr} /{ }^{86} \mathrm{Sr}$ and lower $\epsilon_{\mathrm{Nd}}$ than those from the Radio Towers cluster. Alkali basalts from Grass Valley were derived from magma type B. Grass Valley alkali basalts have ${ }^{87} \mathrm{Sr} /$ ${ }^{86} \mathrm{Sr}=0.7037-0.7040, \epsilon_{\mathrm{Nd}}=1.6$ to -0.5 , and ${ }^{206} \mathrm{~Pb} /$ ${ }^{204} \mathrm{~Pb}$ ca. 18.05. Magma type $\mathrm{C}$ consists of alkali basalts from Ivan's Knoll that have ${ }^{87} \mathrm{Sr} /{ }^{86} \mathrm{Sr}=$ 

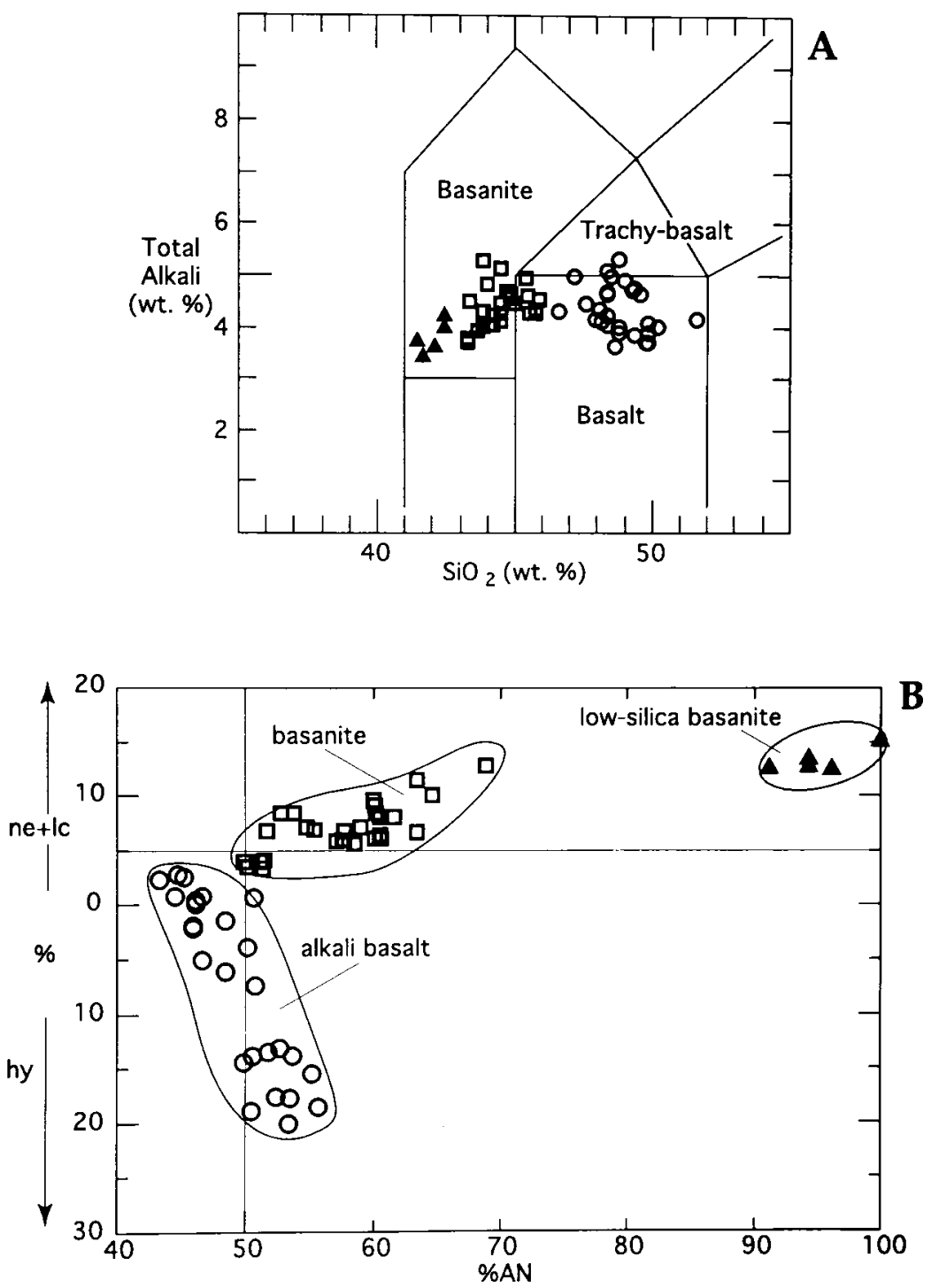

Figure 3. A, Volcanic rocks of the Hurricane volcanic field are mainly basanites and alkali basalts on a total alkali versus $\mathrm{SiO}_{2}$ diagram (modified from La Bas et al. 1986). B, On the basis of a classification scheme similar to that of Best and Brimhall (1974), we divide the mafic rocks into alkali basalt (circles), basanites (squares), and low-silica basanites (filled triangles). Percentage normative anorthite $(\% A N)$ is plotted against normative hypersthene (hy), nepheline (ne), and leucite (lc).

$0.7046-0.7049, \epsilon_{\mathrm{Nd}}=-6.2$ to -7.5 , and ${ }^{206} \mathrm{~Pb} /{ }^{204} \mathrm{~Pb}$ ca. 17.5. Magma type D contains low-silica basanite from the Remnants and has ${ }^{87} \mathrm{Sr} /{ }^{86} \mathrm{Sr}=$ $0.7046-0.7048, \epsilon_{\mathrm{Nd}}=-1$ to -1.4 , and ${ }^{206} \mathrm{~Pb} /{ }^{204} \mathrm{~Pb} \mathrm{ca}$. 18.6. Magma types $\mathrm{A}, \mathrm{B}$, and D plot just to the left and below the Great Basin OIB array of Fitton et al. (1988) in a field defined by the range of isotopic variation of basalts on the Colorado Plateau (fig. $6 A$ ). Falling outside this field is type C, from Ivan's Knoll and the flow underlying Hurricane Valley, which has significantly lower ${ }^{143} \mathrm{Nd} /{ }^{144} \mathrm{Nd}$ ratios (0.512253-0.512322 and $\epsilon_{\mathrm{Nd}}=-6.2$ to -7.5$)$. All samples from Hurricane plot above the Northern Hemisphere reference line and form a trend of decreasing ${ }^{206} \mathrm{~Pb} /{ }^{204} \mathrm{~Pb}$ with slightly decreasing ${ }^{207} \mathrm{~Pb} /$ ${ }^{204} \mathrm{~Pb}$ on lead isotope plots (fig. $6 B$ ).

Evolution of the Volcanic Field. We focused our efforts on three problems concerning the evolution of the mafic volcanic rocks of the Hurricane volcanic field: (1) the effects of crustal contamination 
Table 3. Summary of Chemistry for Hurricane Volcanic Field Magma Types

\begin{tabular}{|c|c|c|c|c|}
\hline & \multicolumn{4}{|c|}{ Magma type } \\
\hline & A & B & $\mathrm{C}$ & $\mathrm{D}$ \\
\hline Time stage & Stage $4 a, b$ & Stage 3 & Stage $2 b$ & Stage $2 a$ \\
\hline Rock class & Basanite & Alkali basalt & Alkali basalt & Low- $\mathrm{SiO}_{2}$ basanite \\
\hline $\mathrm{SiO}_{2}$ wt $\%$ & $43.3-45.9$ & $47.2-49.6$ & $48.4-51.6$ & $41.5-42.5$ \\
\hline \multicolumn{5}{|l|}{$\begin{array}{l}\text { Magnesium } \\
\text { number }\end{array}$} \\
\hline average & 63.9 & 61.0 & 54.8 & 69.7 \\
\hline $\mathrm{Ba} / \mathrm{Nb}$ average & 14.2 & 15.2 & 42.9 & 27.6 \\
\hline Initial ${ }^{87} \mathrm{Sr} /{ }^{86} \mathrm{Sr}$ & .704189 & .703810 & .704751 & .704687 \\
\hline$\epsilon_{\mathrm{Nd}}$ & -.2 to -1.8 & 1.6 to -.5 & -6.2 to -7.5 & -1.0 to -1.4 \\
\hline${ }^{206} \mathrm{~Pb} /{ }^{204} \mathrm{~Pb}$ & 18.31 & 18.03 & 17.49 & 18.64 \\
\hline
\end{tabular}

on basalt chemistry, (2) the characterization of the mantle source region, and (3) the chemical complexity of individual centers in the volcanic field.

Crustal Contamination. Although many geochemical parameters indicate a mantle source for Hurricane magmas (high magnesium numbers, trace element patterns, and isotopic ratios), there are important questions concerning crustal contamination and the character of the mantle source (asthenosphere or lithosphere). Previous studies on the Colorado Plateau have identified five lower crustal components that may be likely contaminants of Hurricane magmas (Perry et al. 1987; Nealey and Unruh 1991; Nealey et al. 1993; Unruh et al. 1994; Arculus and Gust 1995). Although the fields of Hurricane lavas point toward lower crust (fig. 6A) and contamination appears to be qualitatively attractive, contamination is unreasonable because:

1. The Nd content of most of the lower crustal xenoliths is too low (usually $<10 \mathrm{ppm}$ ) to signifi- cantly change $\epsilon_{\mathrm{Nd}}$ values without adding $70 \%-85 \%$ lower crust. This amount of contamination is unreasonable because the rocks do not contain any mega- or microscopic evidence for contamination. Furthermore, such large amounts of contamination are thermodynamically difficult because a considerable amount of heat is required to assimilate crustal rock; the magmas would cool quickly and perhaps "freeze" in place.

2. Low-silica basanite and basanite magmas (types A and B) have primitive chemistry (high $\mathrm{MgO}$, magnesium numbers, and high concentrations of compatible elements) and probably rose rapidly enough from their site of partial melting to the surface to escape significant crustal contamination.

3. Types $\mathrm{A}$ and $\mathrm{B}$ show a $\epsilon_{\mathrm{Nd}}$ spread of over two units, but many trace elements (e.g., $\mathrm{Zr}, \mathrm{Nd}$, and $\mathrm{Sr}$ ) have remarkably similar concentrations over this range. This observation is inconsistent with

Table 4. Summary of Average Chemical Analyses from Each Volcanic Center in the Hurricane Volcanic Field

\begin{tabular}{|c|c|c|c|c|c|c|c|}
\hline & $\begin{array}{l}\text { The Divide } \\
\text { (basanite) }\end{array}$ & $\begin{array}{c}\text { Radio } \\
\text { Towers } \\
\text { (basanite) }\end{array}$ & $\begin{array}{l}\text { Volcano } \\
\text { Mountain } \\
\text { (basanite) }\end{array}$ & $\begin{array}{c}\text { Cinder Pits } \\
\text { (alkaline basalt) }\end{array}$ & $\begin{array}{c}\text { Grass Valley } \\
\text { (alkaline basalt) }\end{array}$ & $\begin{array}{c}\text { Ivan's Knoll } \\
\text { (alkaline basalt) }\end{array}$ & $\begin{array}{l}\text { Remnants } \\
\text { (low-silica } \\
\text { basanite) }\end{array}$ \\
\hline Magma & A & A & A & & B & $\mathrm{C}$ & $\mathrm{D}$ \\
\hline $\mathrm{SiO}_{2}$ & 44.0 & 45.4 & 45.6 & 48.3 & 48.6 & 49.5 & 42.0 \\
\hline $\mathrm{Al}_{2} \mathrm{O}_{3}$ & 11.3 & 13.0 & 12.8 & 15.0 & 16.0 & 16.0 & 12.0 \\
\hline $\mathrm{Fe}_{2} \mathrm{O}_{3}$ & 13.1 & 12.6 & 12.8 & 11.1 & 10.1 & 11.1 & 11.7 \\
\hline $\mathrm{MgO}$ & 12.5 & 10.4 & 10.6 & 7.7 & 8.0 & 7.1 & 13.6 \\
\hline $\mathrm{TiO}_{2}$ & 2.58 & 2.28 & 2.43 & 1.74 & 1.79 & 1.58 & 1.86 \\
\hline $\begin{array}{l}\text { Magnesium } \\
\text { number }\end{array}$ & 65.3 & 62.6 & 62.1 & 58.1 & 61.0 & 54.8 & 69.7 \\
\hline $\mathrm{Rb}$ & 19.0 & 20.0 & 17.3 & 13.5 & 12.1 & 12.1 & 12.2 \\
\hline $\mathrm{Ba}$ & 766 & 993 & 990 & 823 & 381 & 678 & 2243 \\
\hline $\mathrm{Nb}$ & 64.2 & 53.4 & 50.9 & 30.2 & 25.2 & 17.8 & 81.8 \\
\hline Th & 7.50 & 7.01 & 6.49 & 5.02 & 3.39 & 2.03 & 18.65 \\
\hline $\mathrm{Sr}$ & 885 & 890 & 890 & 664 & 756 & 614 & 1230 \\
\hline $\mathrm{Cr}$ & 466 & 421 & 414 & 300 & 294 & 181 & 607 \\
\hline $\mathrm{Ni}$ & 360 & 198 & 215 & 143 & 157 & 68 & 312 \\
\hline
\end{tabular}

Note. Oxide values in wt \%, trace element values in ppm. 

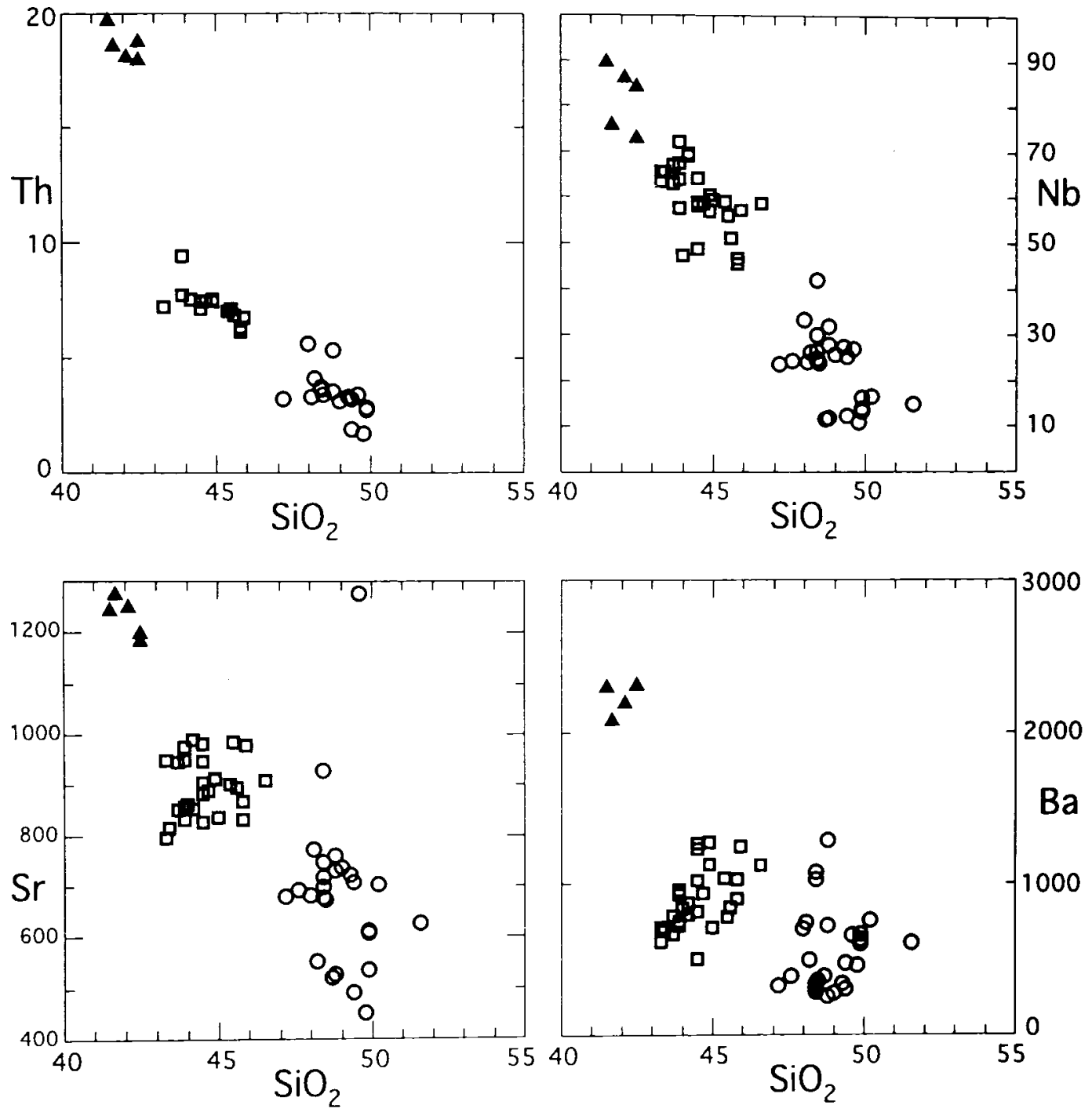

Figure 4. Th, $\mathrm{Nb}, \mathrm{Sr}$, and $\mathrm{Ba}$ in general decrease as $\mathrm{SiO}_{2}$ increases when considering the entire Hurricane volcanic field. Symbols are the same as in figure 3.

contamination because it would require that the contaminant have nearly the same trace element budget as the host magmas. This situation is highly unlikely; in fact, xenoliths with the trace element concentrations of types $\mathrm{A}$ and $\mathrm{B}$ are unknown.

4. Inconsistencies in relative order of increasing contamination argue against contamination as a model. For example, when considering ${ }^{87} \mathrm{Sr} /{ }^{86} \mathrm{Sr}$ and $\epsilon_{\mathrm{Nd},}$ it appears that magma type $\mathrm{B}$ is the least contaminated and type $\mathrm{C}$ was most affected (fig. $6 \mathrm{~A}$ ). However, $\mathrm{Pb}$ isotopes indicate that type $\mathrm{D}$ is the least and type $C$ the most contaminated (fig. $6 B$ ).

Based on these arguments, we eliminate crustal contamination as a cause of both inter- and intragroup chemical variation.

Mantle Source. Basalts derived from lithospheric mantle in the Great Basin and Colorado Plateau have higher ${ }^{87} \mathrm{Sr} /{ }^{86} \mathrm{Sr}$, large ion lithophile $(\mathrm{Sr}, \mathrm{Ba})$, and LREE (La and Ce) element abundances and lower $\epsilon_{\mathrm{Nd}}, \mathrm{Nb}, \mathrm{Ta}, \mathrm{Zr}$, and $\mathrm{Ti}$ than those produced by melting of asthenospheric mantle. The lithospheric mantle in this area may represent a mixture of oceanic crust and the sedimentary component of an accretionary wedge added to the lithosphere by subduction at $>1 \mathrm{Ga}$. Isolation from the convecting asthenospheric for long periods of time al- 


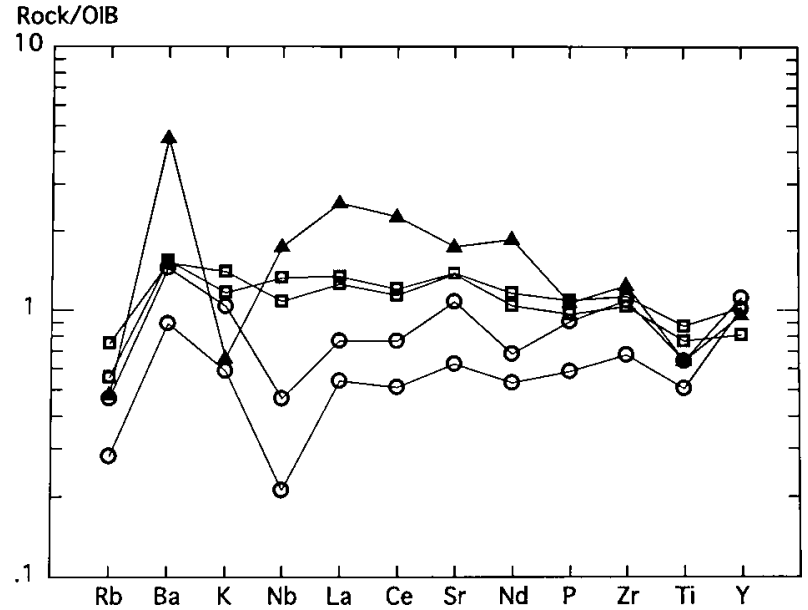

Figure 5. Hurricane basalts are similar to the oceanisland basalt (OIB) of Fitton et al. (1991). Low-silica basanites (filled triangles) show enrichment in Ba and LREE but depletion in $\mathrm{K}$. Alkali basalts show depletion in $\mathrm{Nb}$. In this plot, samples 5-6, and 6-2 were used to represent basanites, 1-5 and 7-17 alkali basalt and 6-12 low-silica basanite. Symbols are the same as in figure 3 .

lowed isotopic ratios to evolve to present-day values. As a result of these differences in chemistry between lithospheric and asthenospheric mantle, a combination of HFSE-LREE ratios and isotopic data is useful for identifying mantle source. Especially helpful is the $\mathrm{Nb}-\mathrm{La}$ ratio. Because high field strength elements like $\mathrm{Nb}$ are depleted in the lithospheric mantle relative to the LREEs, low $\mathrm{Nb} / \mathrm{La}$ suggests a source in the lithospheric mantle and higher $\mathrm{Nb} / \mathrm{La}$ indicates OIB-like asthenospheric mantle (fig. 7). Alkali basalt from Ivan's Knoll (magma type $\mathrm{C}$ ) with low $\mathrm{Nb} / \mathrm{La}$ and $\mathrm{Nb}, \mathrm{Zr}$, and Ti troughs on spider diagrams and low $\epsilon_{\mathrm{Nd}}$ was most likely derived from a lithospheric mantle source (fig. 5). Although types A, B, and D have relatively high $\mathrm{Nb} / \mathrm{La}$ values $(0.7-1.1)$, suggesting an asthenosphere mantle (OIB-like) source, their position extends below the field of OIB toward lithospheric mantle values (fig. 7), indicating that the source is not typical OIB-like mantle. Ruling out crustal contamination, these magmas may reflect the mixing of asthenospheric and lithospheric mantle sources or represent melts of the lithospheric mantle. These processes are evaluated in the next sections.

A popular model to explain the isotopic and trace element signatures of transition zone and Basin and Range basalts involves mixing between components derived from a depleted asthenospheric source with those from a relatively enriched lithospheric mantle source (e.g., Cooper and Hart
1990). Recent geochemical studies, thorium isotopic evidence, and helium isotope variations, however, argue against this model. According to Hawkesworth et al. (1995), partial melting of the

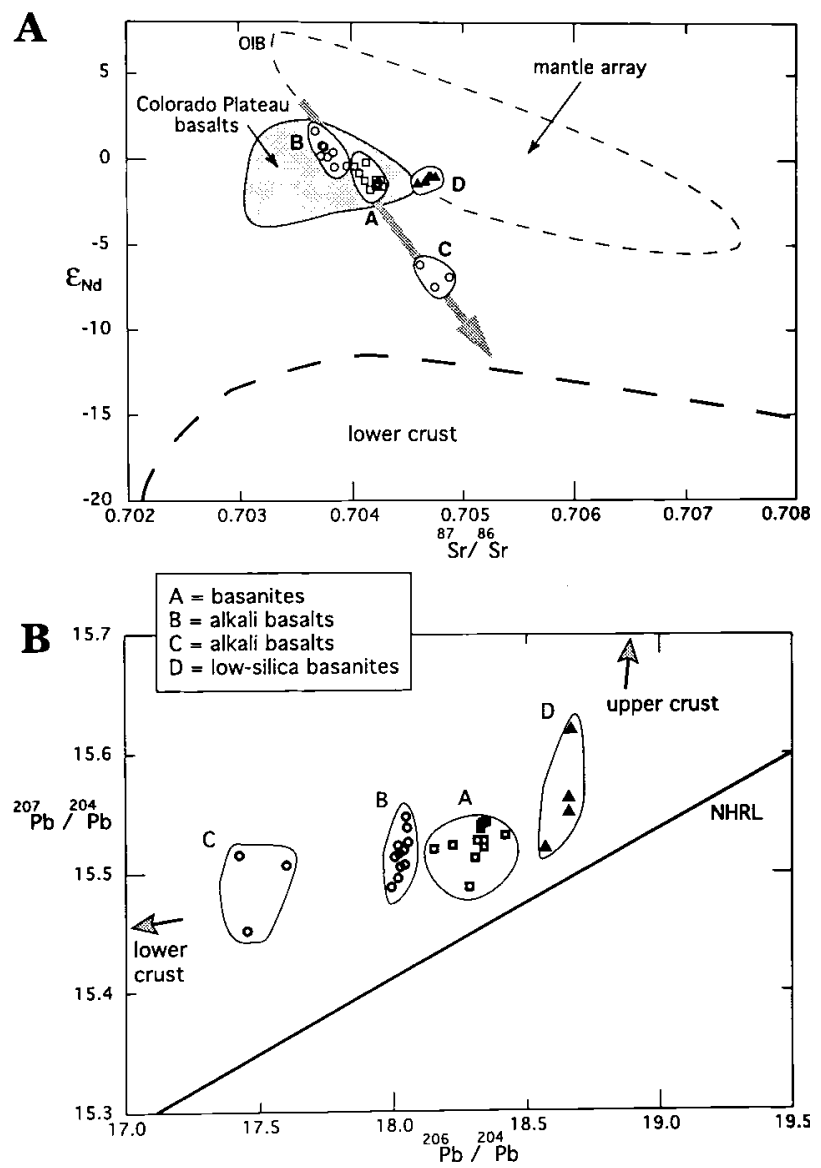

Figure 6. $A$, Five cone clusters are divided into four isotopic groups on an $\epsilon_{\mathrm{Nd}}$ versus ${ }^{87} \mathrm{Sr} /{ }^{86} \mathrm{Sr}$ plot. The isotopic groups plot below the mantle array (Bradshaw et al. 1993) but fall in the field of typical Colorado Plateau basalts (Alibert et al. 1986; except group C). The field for lower crust is based on the composition of xenoliths inferred to have originated in the lower crust. The field was constructed from the following sources; Arculus and Gust (1995; San Francisco Volcanic field), Nealey and Unruh (1991; Tule Tank), Perry et al. (1987; Taos Plateau), Nealey et al. (1993; Markagunt Plateau), and Unruh et al. (1994; St. George Basin). The broad arrow through isotopic groups $B, A$, and $C$ depicts a model of lower crustal contamination. Although crustal contamination appears to be qualitatively attractive, the model is unreasonable (see "Crustal Contamination"). B, Isotopic groups plot above the Northern Hemisphere Reference Line $(N H R L)$ on a ${ }^{206} \mathrm{~Pb} /{ }^{204} \mathrm{~Pb}$ versus ${ }^{207} \mathrm{~Pb} /{ }^{204} \mathrm{~Pb}$ diagram. Arrows point toward the fields of lower crust (Wooden and Miller 1990) and upper crust (Wilson 1989). Symbols on both plots are the same as in figure 3 . 


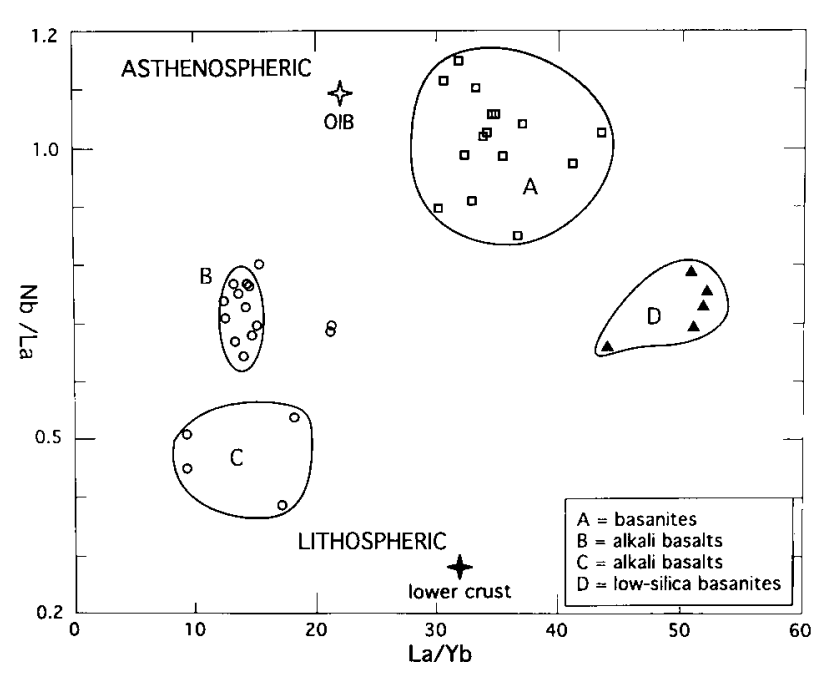

Figure 7. $\mathrm{Nb}$ is commonly depleted in the lithospheric mantle relative to $\mathrm{La}$, so low $\mathrm{Nb} / \mathrm{La}$ for mafic magmas suggests a lithospheric mantle source and higher ratios an OIB-like asthenospheric mantle source (diagram modified from Bradshaw and Smith 1994). Open cross, average OIB from Fitton et al. (1991); filled cross, average of six granulite xenoliths from the lower crust /Chen and Arculus 1995).

asthenospheric mantle was a rare event because of the small volumes of magmatic rocks in the Basin and Range with chemical signatures of oceanic basalts. This component, therefore, would not be available in large volumes to mix with melts derived from the lithospheric mantle. Studies by Reid and Ramos (1996) show that mixing of asthenospheric and lithospheric melts cannot account for the covariation in $\mathrm{Nd}$ and $\mathrm{Th}$ isotopes for Basin and Range and southwest Utah basalts. Furthermore, ${ }^{3} \mathrm{He} /{ }^{4} \mathrm{He}$ values of $5.5-6.3 \mathrm{R}_{\mathrm{A}}$ for southwestern Utah lavas (Reid and Graham 1996) imply a source in the lithospheric mantle with little or no asthenospheric component. On the basis of these studies, they conclude that Quaternary and Holocene basalts in the southwestern United States originated by melting of a compositionally heterogeneous lithospheric mantle without either OIB-like asthenospheric or crustal additions. We agree with their hypothesis and suggest that the different magma types of Hurricane basalts reflect the partial melting of a compositionally heterogeneous lithospheric mantle; an OIB-like asthenospheric mantle component is probably not involved.

The relatively large variation in $\mathrm{Ce} / \mathrm{Yb}$ and the low values of $\mathrm{Yb}$ (fig. 8) suggest that $\mathrm{Yb}$ may have been compatible during partial melting. These observations are consistent with the presence of re- sidual garnet in the source. Consequently, partial melting models use a garnet-bearing source composition based on an average of fertile garnet lherzolite (enriched mantle) analyses from Arizona (Ehrenberg 1982). This source has a Ce/Yb of about 3 and $\mathrm{Yb}$ of 0.6 (values normalized to primitive mantle; Bradshaw et al. 1993). The model curves in figure 8 use a simple equilibrium melting equation (Gast 1968) and modal source mineralogy and solidliquid distribution coefficients from Bradshaw et al. (1993). The Hurricane data are approximated by $0.5 \%-7 \%$ partial melting of an olivine-orthopyroxene-clinopyroxene-garnet source containing $1-5 \mathrm{wt}$ $\%$ garnet. The sources for the different magmatic groups differ mainly in the abundance of garnet. Alkali basalt is approximated by $2 \%-7 \%$ partial melting of a mantle source with 1-2.5 wt \% garnet, basanites by $2 \%-3 \%$ partial melting of garnet lherz-

olite with 4-5 wt \% garnet, and low-silica basanites by $<1 \%$ partial melting of a source with $2.5-4 \mathrm{wt}$ $\%$ garnet. Differences in incompatible element

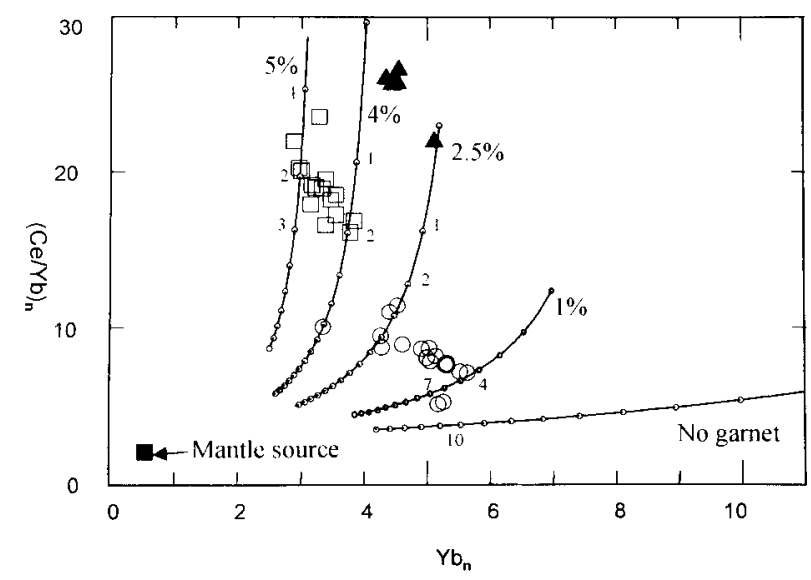

Figure 8. Primitive mantle normalized $\mathrm{Ce} / \mathrm{Yb}$ versus $\mathrm{Yb}$ for Hurricane Volcanic field mafic rocks. Mantle source is a fertile garnet lherzolite (Ehrenberg 1982), partial melting curves for $5 \%, 4 \%, 2.5 \%, 1 \%$, and $0 \%$ garnet were calculated using an equilibrium melting equation (Gast 1968). Small circles on melting curves mark 1\% melting intervals. The Hurricane data are approximated by $0.5 \%-7 \%$ partial melting of an olivine (60-61 wt \%)orthopyroxene (20-24 wt \%)-clinopyroxene (14-15 wt $\%$ )-garnet source containing 1-5 wt \% garnet. The sources for the different magmatic groups differ mainly in the abundance of garnet. Alkali basalts (open circles) are approximated by $2 \%-7 \%$ partial melting of a mantle source with 1-2.5 wt \% garnet; basanites (open squares), $2 \%-3 \%$ partial melting of garnet; lherzolite, $4-5 \mathrm{wt} \%$ garnet; and low-silica basanites (solid triangles), $<1 \%$ partial melting of a source with $2.5-4 \mathrm{wt} \%$ garnet. 


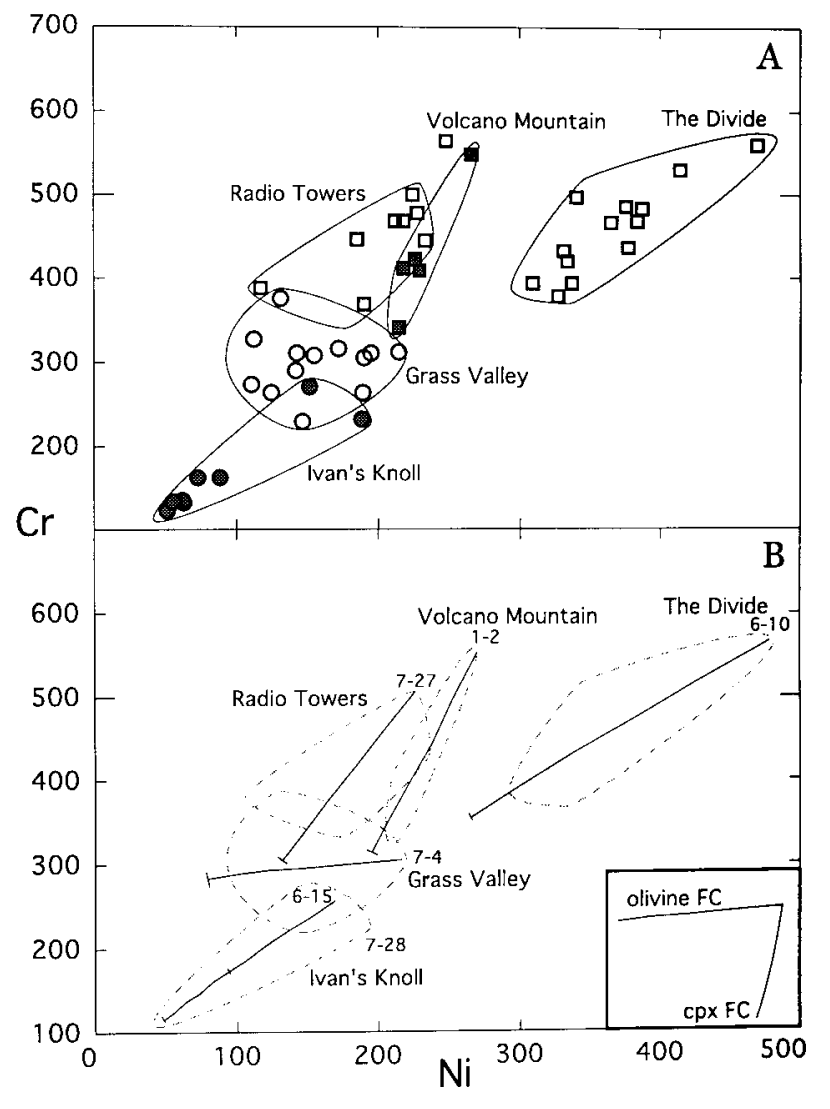

Figure 9. $A, \mathrm{Cr}$ versus Ni diagram showing Hurricane Volcanic field mafic rocks grouped by cone and rock type. Symbols are the same as in figure 7 except Volcano Mountain and Ivan's Knoll samples use shaded symbols. $B$, Olivine and clinopyroxene fractional crystallization models are used to explain the compositional variation in each cone. The parent rock for each cone is denoted by its sample number. Tick marks on model lines are at $10 \%$ intervals. The insert shows evolution curves for crystallization of olivine and clinopyroxene.

contents among the major groups (fig. 4) may be entirely explained, therefore, by differences in the degree of partial melting. Partial melting calculations support a heterogeneous mantle model for the Hurricane area but suggest that differences in mantle composition are small, at least at the scale of the Hurricane volcanic field. Nevertheless, different degrees of partial melting of this heterogeneous source are effective in producing the parental magmas for each isotopic groups and perhaps for each volcano cluster.

Variation within Rock Groups. Models involving fractional crystallization (FC) were used to explain chemical variation within magma groups. Computer modeling of these processes was done using IGPETWIN software (Carr 1994). Minor oxide and trace element distribution coefficients for mafic volcanic rocks were compiled from various sources and are listed in table 7.

We developed petrogenetic models on a $\mathrm{Cr}$ versus $\mathrm{Ni}$ diagram (fig. 9). On this plot, lavas related to each cone cluster lie in a different position and have a different trend. $\mathrm{Cr}$ and $\mathrm{Ni}$ are compatible elements; $\mathrm{Cr}$ is especially compatible in clinopyroxene, spinel, and hornblende and $\mathrm{Ni}$ in olivine and, to a lesser degree, in clinopyroxene, spinel, and hornblende. FC of olivine will produce nearly flat evolution lines that rapidly decrease in Ni. Because of the large difference in distribution coefficients between $\mathrm{Cr}$ and $\mathrm{Ni}$ for olivine (1.65 and 10, respectively), the evolution line will remain relatively flat up to about $30 \%$ olivine fractionation. Above this value, it curves to lower values of $\mathrm{Cr}$. The evolution lines for both clinopyroxene and olivine are steep with $\mathrm{Cr}$, rapidly decreasing to ca. $30 \%$ FC, where they begin to curve toward lower values of Ni. Considering only olivine and clinopyroxene, removing combinations of these minerals will produce evolution lines that lie in the envelope bounded by the olivine and clinopyroxene curves (fig. 9). Fractionation of olivine with spinel inclusions will increase the amount of $\mathrm{Cr}$ and $\mathrm{Ni}$ being withdrawn from the magma; therefore, less FC would be required for each model if spinel is included. Because the mineralogy of the spinel in Hurricane samples is unknown, spinel was not used in any of the models.

The first model we considered involves FC of various proportions of olivine and clinopyroxene to explain the chemical variation on the $\mathrm{Cr}$ versus $\mathrm{Ni}$ diagram. FC models vary from olivine only (Grass Valley) to $1: 3$ olivine : clinopyroxene ratio (Volcano Mountain; fig. 9). The absolute amount of FC is reasonable and varies from $6 \%$ for the Radio Towers to $21 \%$ for the Ivan's Knoll cluster. The parent rock for each of the cones was selected on the basis of the highest $\mathrm{Cr}$ and $\mathrm{Ni}$. Note the similar composition for the Volcano Mountain and Radio Towers parent rocks. Perhaps these cones share the same parent magma but, during their evolution, different proportions of mineral phases were removed, thus explaining their different evolution trends. These models are confirmed when considering other trace elements. For example, increasing incompatible element contents ( $\mathrm{Nb}, \mathrm{Zr}, \mathrm{Y}, \mathrm{Ba}, \mathrm{Sr})$ with decreasing $\mathrm{Ni}$ and $\mathrm{Cr}$ are in accord with $\mathrm{FC}$ of olivine and clinopyroxene (fig. 10). The only exceptions are lavas from Volcano Mountain that display a decrease of most incompatible trace elements with decreasing $\mathrm{Cr}$ and Ni. Perhaps contamination or magma mixing can explain these 


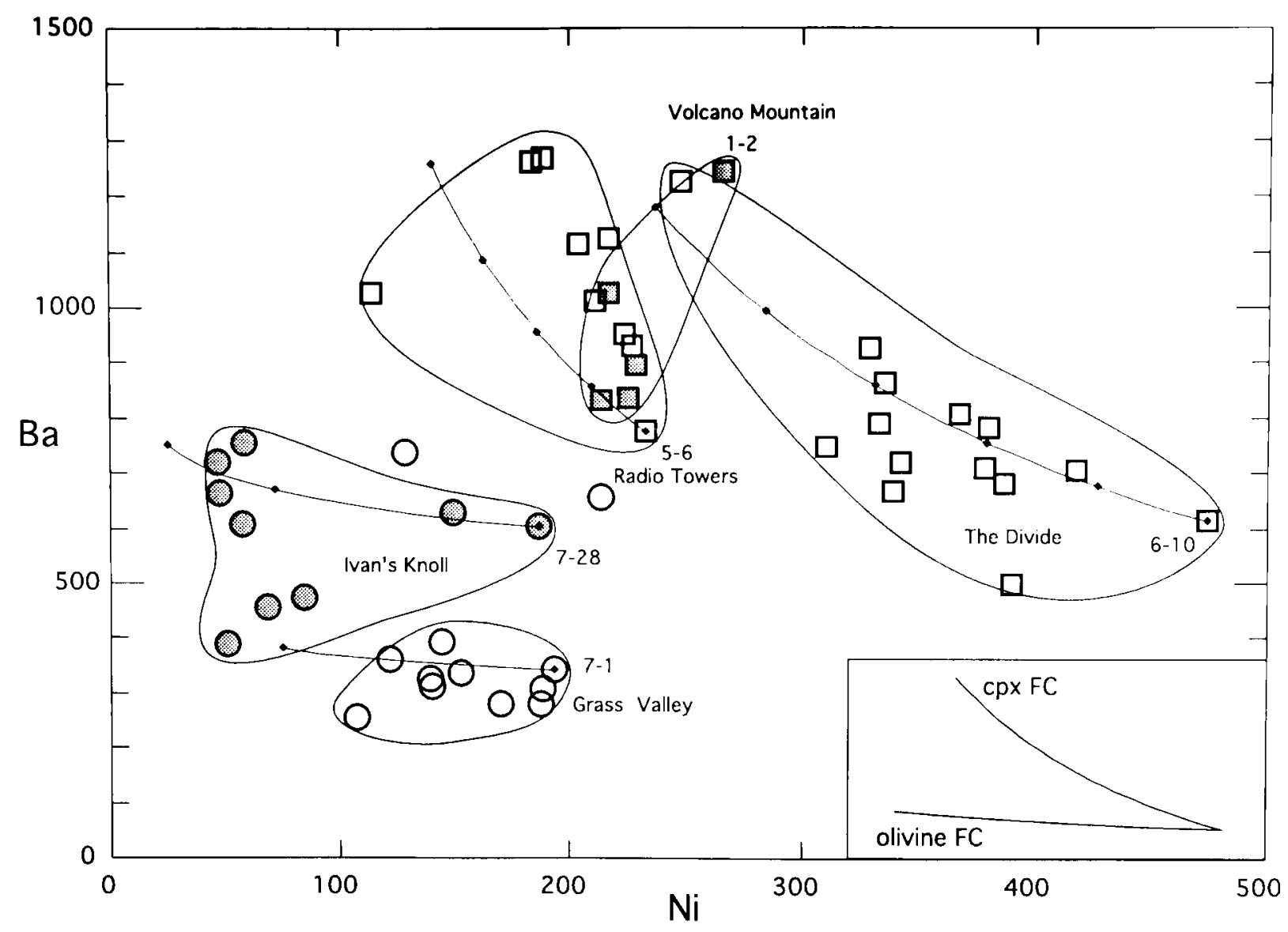

Figure 10. Using an incompatible element (Ba) versus compatible element (Ni) plot, fractional crystallization of olivine and clinopyroxene explain variation in lavas of each cone. Volcano Mountain is an exception; another process, perhaps magma mixing, may be complicating its evolution. Symbols are the same as in figure 9. Insert shows evolution curves for divine and clinopyroxene in Ba-Ni space. Tick marks on model lines shown at $5 \%$ intervals.

chemical trends. However, no appropriate contaminant or magma has been identified.

\section{Regional Comparison}

The transition zone separates the Basin and Range from the Colorado Plateau and forms the eastern margin of the Great Basin and the northern margin of the southern Basin and Range. To determine the changes that occur across the boundary between the Basin and Range and the transition zone, we considered a transect from the Basin and Range to the transition zone consisting of the Fortification Hill volcanic field in the northern Colorado River extensional corridor, an area of thin lithosphere in the Basin and Range province; the Grand Wash Trough at the western boundary between the Basin and Range and transition zone; and the Hurricane volcanic field within the transition zone. Isotopic values for the Pliocene alkali basalts in the Fortification Hill volcanic field (Feuerbach et al. 1993) lie within the mantle array in the field of ocean island basalt of Fitton et al. (1991). Isotopic ratios for alkali basalts in the Grand Wash Trough (Cole 1989) have lower $\epsilon_{\mathrm{Nd}}$ values than the basalts of the Fortification Hill field and a steeper negative slope on a ${ }^{87} \mathrm{Sr} /{ }^{86} \mathrm{Sr}$ versus $\epsilon_{\mathrm{Nd}}$ diagram (fig. 11). Rocks from the Hurricane volcanic field have isotopic values that plot to the lower left of the mantle array with lower $\epsilon_{\mathrm{Nd}}$ and ${ }^{87} \mathrm{Sr} /{ }^{86} \mathrm{Sr}$. The trends defined by the three volcanic fields along the transect swing from the mantle array (Basin and Range) toward lower $\epsilon_{\mathrm{Nd}}$ and ${ }^{87} \mathrm{Sr} /{ }^{86} \mathrm{Sr}$ (transition zone). The field of Colorado Plateau basalt (Alibert et al. 1986) continues this trend toward lower $\epsilon_{\mathrm{Nd}}$ and ${ }^{87} \mathrm{Sr} /{ }^{86} \mathrm{Sr}$.

The explanation for the changing isotopic pattern with location along the transect remains controversial. One possible explanation relates changes 

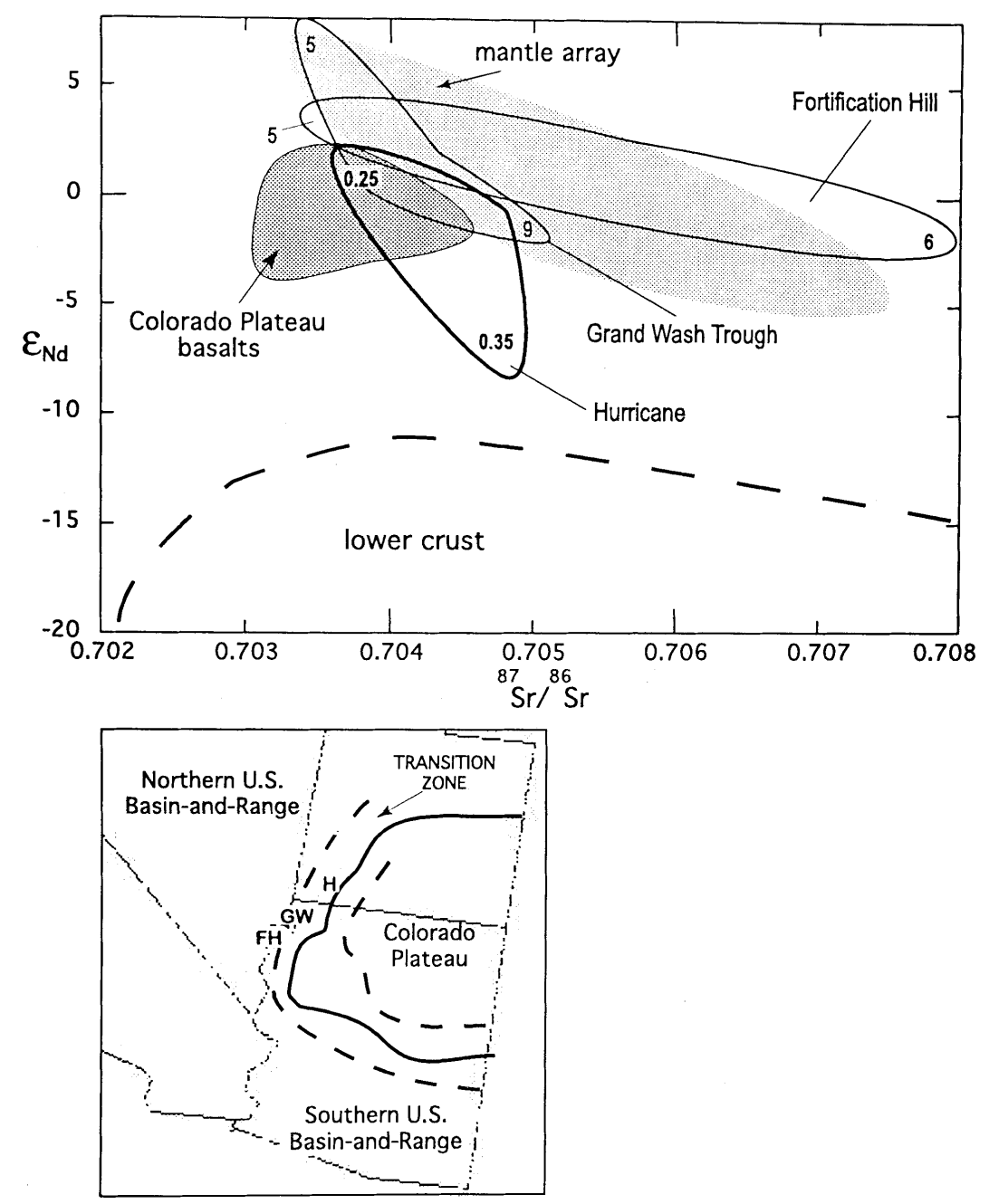

Figure 11. Comparison of volcanic fields along a transect from the Basin and Range to the Colorado Plateau. Mantle array from Bradshaw et al. (1993); Fortification Hill, Feuerbach et al. (1993); Grand Wash Trough, Cole (1989); and Colorado Plateau, Alibert et al. (1986). Numbers within each field are ages in Ma. The field for lower crust was constructed using references cited in the caption to figure 6. Lower panel shows location of the volcanic fields $(F H=$ Fortification Hill, $G W=$ Grand Wash Trough, $H=$ Hurricane $)$ and tectonic province boundaries. Dashed lines outline the transition zone; the solid line is the boundary between the Colorado Plateau and Basin and Range provinces.

in isotopic ratios to changing proportions of asthenospheric and lithospheric mantle in the source. Although Basin and Range basalts along the transect were melted from asthenospheric mantle (Feuerbach et al. 1993), it is unlikely that transition zone or Colorado Plateau basalts contain this component. There is some controversy about this interpretation. Basalts on the margins of the Basin and Range in the Colorado Plateau transition zone and in the Western Great Basin isotopic province show depletion in HFSEs ( $\mathrm{Nb}$ and $\mathrm{Ta}$ ) and have higher ${ }^{87} \mathrm{Sr} /{ }^{86} \mathrm{Sr}$ and lower $\epsilon_{\mathrm{Nd}}$ than OIB and according to many studies represent melting of a lithospheric mantle source (Menzies et al. 1983; Kemp- ton et al. 1991; Ormerod et al. 1991; Beard and Glazner 1995; Rodgers et al. 1995; Cousens 1996; Reid and Ramos 1996). Wenrich et al. (1995), however, suggested that transition zone basalts originated in the asthenospheric mantle, though recent helium and thorium isotopic evidence makes this suggestion unlikely and supports the lithospheric mantle as the most likely source (Reid and Ramos 1996; Reid and Graham 1996).

A second hypothesis depends on variable crustal contamination with more contamination occurring where the lithosphere is thick and less where it is thin. An important fact revealed by seismic refraction profiles (Allmendinger et al. 1987) is that the 


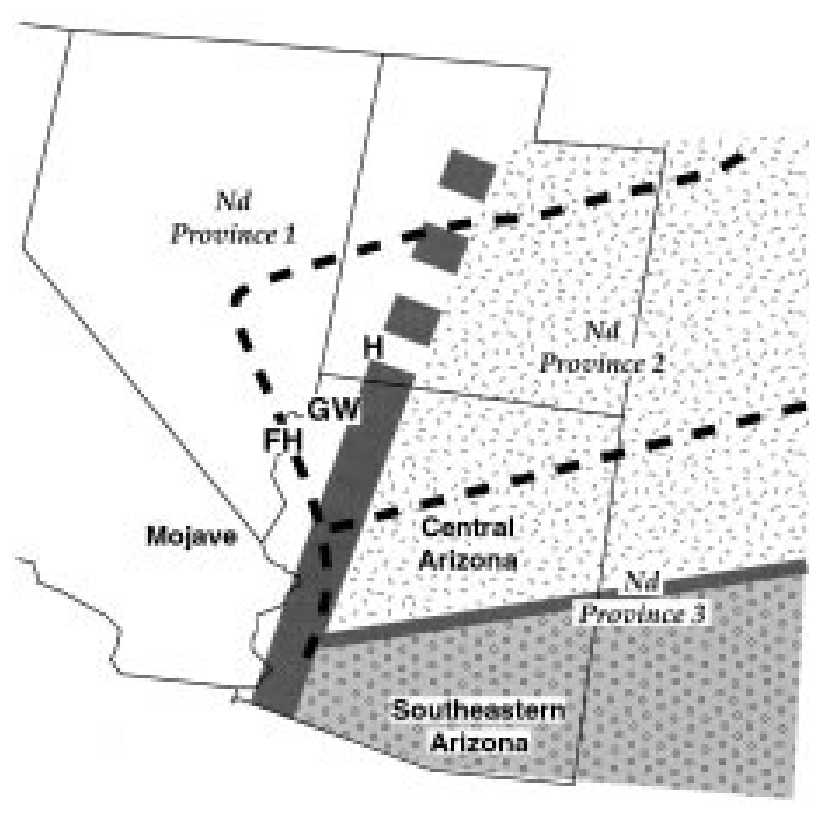

Figure 12. Early Proterozoic isotopic provinces in the southwestern United States modified from Wooden and Miller (1990). Light shading, Mojave Pb province. Dark shading, the Arizona-Colorado-New Mexico Pb province. Intermediate shading, boundary zone between the two $\mathrm{Pb}$ provinces. Heavy dashed lines, boundaries between Nd provinces of Bennett and DePaolo (1987). $F H=$ Fortification Hill, $G W=$ Grand Wash Trough, $H=$ Hurricane.

lithosphere thins from 40 to $25 \mathrm{~km}$ from the Colorado Plateau to the Basin and Range. Although there are examples of lower crust partially controlling basalt composition on the Colorado Plateau (Nealey and Unruh 1991; Chen and Arculus 1995; Blaylock et al. 1996), crustal contamination is unlikely to have affected the composition of Hurricane Lavas. In addition, crustal contamination of mafic magmas occurs in the Basin and Range (Foland and Bergman 1992; Yogodzinski et al. 1996) as well as on the Colorado Plateau. There is, therefore, no correlation between geographic position and areas of contaminated mafic magmas.

Ruling out asthenospheric components in the source of mafic magmas and crustal contamination in the transition zone-Colorado Plateau part of the transect leaves the melting of a heterogeneous lithospheric mantle as the most viable mechanism for producing the observed chemical variability. If isotopic and chemical variability reflect large-scale mantle heterogeneity, basalt chemistry may be revealing differences in composition of mantle formed at the time of its addition to the lithosphere at $>1 \mathrm{Ga}$. A heterogeneous lithospheric mantle is expected because lithospheric mantle was created by fragments of subducted oceanic lithosphere and sediments of the accretionary wedge added to the lithosphere at different times. Accretion must have occurred at $\geq 1 \mathrm{Ga}$ (if not earlier) to allow isotopic systems to evolve from MORB values to presentday enriched signatures. Consequently, basalt geochemistry may be providing insight into the chemical makeup of the mantle lithosphere of the North American Plate. Furthermore, chemical variations from the Basin and Range to the Colorado Plateau may reflect a lithospheric boundary older and more fundamental than the present-day physiographic and structural boundary between the two provinces.

The transect lies just to the east of a major Early Proterozoic lithospheric boundary defined by $\mathrm{Nd}$ studies (Bennett and DePaolo 1987) and just to the west of the boundary zone between Mojave and Arizona-Colorado-New Mexico Pb crustal provinces defined by Wooden and DeWitt (1991). The $\mathrm{Nd}$ boundary is extrapolated from the Lake Mead area into central northern Nevada and Utah, and the $\mathrm{Pb}$ boundary is projected to the north into Utah (fig. 12). Although speculative, we suggest that one or both of these boundaries crosses the transect line and that the differences in chemistry recorded by the three basalt fields along the transect reflect the boundary between lithospheric provinces. A potential problem with this hypothesis lies in the $\epsilon_{\mathrm{Nd}}$ data reported by Bennett and DePaolo (1987). $\epsilon_{\mathrm{Nd}}$ of crustal rocks in $\mathrm{Nd}$ province 2 to the east of the boundary in northwestern Arizona is higher than for province 1 in the Mojave Desert area of California to the west of the boundary $\left(\epsilon_{\mathrm{Nd}} 2.95\right.$ to -1.13 and 4.5 to 0.28 , respectively). This variation is opposite to that measured in basalt magmas along the transect. Recall, however, that the isotopic provinces are defined on the basis of the chemistry of crustal rocks and that the $\epsilon_{\mathrm{Nd}}$ values reported by Bennett and DePaolo (1987) do not directly record the composition of the lithospheric mantle source for basalt magmas. Therefore, the isotopic signature of the lithospheric mantle associated with each isotope province remains unknown. We suggest that the isotopic ratios of the alkali basalt magmas in the three volcanic fields provide information about the changing chemistry of the lithospheric mantle across this major lithospheric boundary. An important consequence of this observation is that in the Hurricane area the position of the boundary between the Basin and Range and Colorado Plateau (formed during Tertiary and Qua- 
ternary time) was controlled by the location of this older lithospheric boundary.

\section{Summary}

1. The Hurricane volcanic field is a small-volume mafic volcanic field in the Colorado Plateau/Basin and Range transition zone. The minimum volume of the field is about $0.5 \mathrm{~km}^{3}$ with the volume of individual centers ranging from 0.05 to $0.30 \mathrm{~km}^{3}$. Strombolian- and Hawaiian-style eruptions produced thin $(10 \mathrm{~m})$ a'a lava flows and cinder (scoria) cones composed of vesicular basalt, bombs, and agglutinate.

2. Radiometric dating $\left({ }^{40} \mathrm{Ar} /{ }^{39} \mathrm{Ar}\right)$ yielded dates of $353 \pm 45 \mathrm{ka}$ for a flow from Ivan's Knoll and $258 \pm 24 \mathrm{ka}$ for a flow from Volcano Mountain. These dates and geologic relationships demonstrate that volcanoes near Hurricane formed over a period of at least $100 \mathrm{ka}$.

3. Three rock groups, low-silica basanite $(42 \%$ $\left.\mathrm{SiO}_{2}\right)$, basanite $\left(43 \%-46 \% \mathrm{SiO}_{2}\right)$, and alkali basalt $\left(46 \%-52 \% \mathrm{SiO}_{2}\right)$, originated by the partial melting of a compositionally heterogeneous lithospheric mantle. Partial melting calculations suggest that the source is fertile garnet lherzolite (enriched mantle) containing variable amounts of garnet (1-5 wt $\%)$. Melting $(0.5 \%-7 \%)$ of this mantle source may have produced the parental magmas for each rock group and perhaps each volcano cluster. Crustal contamination did not play an important role in their petrogenesis.

4. Isotopic data for Pliocene volcanic rocks along a transect from the Basin and Range to the Colorado Plateau show a swing from asthenospheric properties in the Basin and Range to lower values of $\epsilon_{\mathrm{Nd}}$ toward the Colorado Plateau. The melting of a heterogeneous lithospheric mantle is the most viable mechanism for producing the observed chemical variability. If isotopic and chemical variability reflect large-scale mantle heterogeneities, basalt chemistry may be reflecting differences in the composition of mantle formed at the time of its addition to the lithosphere at ca. $1 \mathrm{Ga}$. In other words, these data may be providing insight into the chemical makeup of the mantle lithosphere of the North American Plate. Chemical differences may reflect a major lithospheric boundary originally defined on the basis of $\mathrm{Nd}$ and $\mathrm{Pb}$ isotopes in crustal rocks. An important consequence of this observation is that in the Hurricane area the position of the boundary between the Basin and Range and Colorado Plateau (formed during Tertiary and Quaternary time) was controlled by the location of this older lithospheric boundary. Finally, an important implication of this work is that lithospheric mantle is heterogeneous at a variety of scales, from $<1 \mathrm{~km}$, as reflected by chemical variability within a single volcanic field, to hundreds of kilometers, as reflected by chemical changes along the transect.

\section{A C K N O W L E D G E N T S}

Funding for much of this work was provided by a grant from the State of Nevada Nuclear Waste Project Office and by a research grant from the Graduate Student Association at the University of Nevada, Las Vegas. We thank the staff of the Phoenix Memorial Laboratory, University of Michigan, for completing the REE analyses and Larry Snee and his staff at the USGS in Denver for the ${ }^{40} \mathrm{Ar} /{ }^{39} \mathrm{Ar}$ analyses. We thank T. Bradshaw, W. Taylor, M. Stewart, S. Morikawa, and D. Nealey for informative discussions. J. Luhr and G. Yogodzinski provided helpful comments and suggestions on an earlier version of this article. Finally, we thank two anonymous referees for constructive and thorough reviews.

\section{REFERENCES CITED}

Alibert, C.; Michard, A.; and Albarede, F. 1986. Isotope and trace element geochemistry of Colorado Plateau volcanics. Geochim. Cosmochim. Acta 50:2735-2750.

Allmendinger, R. W.; Hauge, T. A.; Hauser, E. C.; Potter, C. J.; Klemperer, S. L.; Nelson, K. D.; Kneupfer, P.; and Oliver, J. 1987. Overview of the COCORP $40^{\circ} \mathrm{N}$ transect, western United States: the fabric of an orogenic belt. Geol. Soc. Am. Bull. 98:308-319.

Arculus, R. J., and Gust, D. A. 1995. Regional petrology of the San Francisco volcanic field, Arizona, U.S.A. J. Petrol. 36:827-861.

Beard, B. L., and Glazner, A. F. 1995. Trace element and
Sr and $\mathrm{Nd}$ isotopic composition of mantle xenoliths from the Big Pine Volcanic Field, California. J. Geophys. Res. 100:4169-4179.

Bennett, V., and DePaolo, D. J. 1987. Proterozoic crustal history of the western United States as determined by neodymium isotopic mapping. Geol. Soc. Am. Bull. 99:674-685.

Best, M. G., and Brimhall, W. H. 1974. Late Cenozoic alkalic basaltic magmas in the western Colorado Plateau and the Basin and Range transition zone, U.S.A., and their bearing on mantle dynamics. Geol. Soc. Am. Bull. 85:1677-1690. 
Best, M. G.; McKee, E. H.; and Damon, P. E. 1980. Spacetime-composition patterns of Late Cenozoic mafic volcanism, southwestern Utah and adjoining areas: Am. J. Sci. 280:1035-1050.

Blaylock, J. P.; Smith, E. I.; and Holm, R. 1996. Geochemical investigation of Sunset Crater, Arizona: complex petrogenetic history of a low-volume magmatic system. Geol. Soc. Am. Abstr. Program 28:162.

Bradshaw, T. K. 1991. Tectonics and magmatism in the Basin and Range Province of the western United States. Ph.D. dissertation, Milton Keynes, Open University.

Bradshaw, T. K.; Hawkesworth, C. J.; and Gallagher, K. 1993. Basaltic volcanism in the southern Basin and Range: no role for a mantle plume. Earth Planet. Sci. Lett. 116:45-62.

Bradshaw, T. K., and Smith E. I. 1994. Polygenetic Quaternary volcanism at Crater Flat, Nevada. J. Volcanol. Geotherm. Res. 63:165-182.

Carr, M. J. 1994. IGPETWIN: Igpet for Windows petrology software. Somerset, Terra Softa.

Chen, W., and Arculus, R. J. 1995. Geochemical and isotopic characteristics of lower crustal xenoliths, San Francisco Volcanic Field, Arizona, U.S.A. Lithos 36: 203-225.

Cole, E. C. 1989. Petrogenesis of Late Cenozoic alkalic basalt near the eastern boundary of the Basin and Range: Upper Grand Wash Trough, Arizona and Gold Butte, Nevada. M.S. thesis, University of Nevada, Las Vegas.

Cooper, J. L., and Hart, W. K. 1990. Mantle sources in the Arizona transition zone and global mantle heterogeneity. Geology 18:1146-1149.

Cousens, B. L. 1996. Magmatic evolution of Quaternary mafic magmas at Long Valley Caldera and the Devils Postpile, California: Effects of crustal contamination on lithospheric mantle-derived magmas. J. Geophys. Res. 101:27,673-27,689.

DePaolo, D. J. 1981. Trace element and isotopic effects of combined wall-rock assimilation and fractional crystallization. Earth Planet. Sci. Lett. 53:189-202.

Ehrenberg, S. N. 1982. Rare-earth element geochemistry of garnet lherzolite and megacrystalline nodules from minette of the Colorado Plateau province. Earth Planet. Sci. Lett. 57:191-210.

Feuerbach, D. L.; Smith, E. I.; Walker, J. D.; and Tangeman, J. A. 1993. The role of the mantle during crustal extension: constraints from geochemistry of volcanic rocks in the Lake Mead area, Nevada and Arizona. Geol. Soc. Am. Bull. 105:1561-1575.

Fitton, J. G.; James, D.; Kempton, P. D.; Ormerod, D. S.; and Leeman, W. P. 1988. The role of lithospheric mantle in the generation of Late Cenozoic basic magmas in the western United States. J. Petrol. Spec. Lithospheric Issue, p. 331-349.

Fitton, J. G.; James, D.; and Leeman, W. P. 1991. Basic magmatism associated with Late Cenozoic extension in the western United States: compositional variations in space and time. J. Geophys. Res. 96: $13,693-13,712$.
Foland, K. A., and Bergman, S. C. 1992. Temporal and spatial distribution of basaltic volcanism in the Pancake and Reveille Ranges north of Yucca Mountain. In Third International Conference on High Level Radioactive Waste Management, American Nuclear Society (LaGrange Park, Ill.), Proc. p. 2366-2371.

Gast, P. W. 1968. Trace element fractionation and the origin of tholeiitic and alkaline magma types. Geochem. Cosmochim. Acta 32:1057-1086.

Govindaraju, K. 1994. 1994 compilation of working values and sample description for 383 geostandards. Geostandards Newsl. Spec. Issue 18, 158 p.

Green, D. H.; Edgan, H. D.; Beasley, P.; Kiss, E.; and Ware, N. G. 1974. Upper mantle source for some hawaiites, mugearites, and benmorites. Contrib. Mineral. Petrol. 48:33-43.

Hamblin, W. K. 1970. Late Cenozoic basalt flows of the western Grand Canyon. In Hamblin, W. K., and Best, M. G., eds. The western Grand Canyon district: Utah Geological Society guidebook to the geology of Utah 23:21-37.

Hausel, W. D., and Nash, W. P. 1977. Petrology of Tertiary and Quaternary volcanic rocks, Washington County, southwestern Utah. Geol. Soc. Am. Bull. 88: 1831-1842.

Hawkesworth, C.; Bradshaw, T.; Gallagher, K.; Hunter, A.; Rogers, N.; and Turner, S. Calc-alkaline magmatism and extension in the Basin and Range. J. Geophys. Res. 100:10,271-10,286.

Hutchison, C. S. 1974. Laboratory handbook of petrographic techniques. New York, Wiley, 527 p.

Kempton, P. D.; Fitton, J. G.; Hawkesworth, C. J.; and Ormerod, D. S. 1991. Isotopic and trace element constraints on the composition and evolution of the lithosphere beneath the southwestern United States. J. Geophys. Res. 96:13,713-13,735.

Le Bas, M. J.; Le Maitre, R. W.; Streckeisen, A.; and Zanettin, B. 1986. A chemical classification of volcanic rocks based on the total alkali-silica diagram. J. Petrol. 27:745-750.

Lemarchand, F.; Villemant, B.; and Calas, G. 1987. Trace element distribution coefficients in alkaline series. Geochim. Cosmochim. Acta 51:1071-1081.

Luhr, J. F., and Carmichael, I. S. E. 1985. Jorullo Volcano, Michoacan, Mexico, 1759-1774: the earliest stages of fractionation in calc-alkaline magmas. Contrib. Mineral. Petrol. 90:142-161.

McBirney, A. R.; Taylor, H. P., Jr.; and Armstrong, R. L. 1987. Parícutin reexamined: a classic example of crustal assimilation in calc-alkaline magma. Contrib. Mineral. Petrol. 95:4-20.

McMillan, N. J., and Dugan, M. A. 1986. Magma mixing as a petrogenetic process in the development of the Taos Plateau Volcanic Field, New Mexico. J. Geophys. Res. 91:6029-6045.

Menzies, M. A.; Leeman, W. P.; and Hawkesworth, C. J. 1983. Isotope geochemistry of Cenozoic volcanic rocks reveals mantle heterogeneity below western U.S.A. Nature 303:205-209.

Mills, J. G. 1991. The Timber Mountain Tuff, south- 
western Nevada volcanic field: geochemistry, mineralogy and petrogenesis. Ph.D. dissertation, Michigan State University, East Lansing.

Nealey, L. D., and Unruh, D. M. 1991. Geochemistry and isotopic characteristics of deep crustal xenoliths from Tule Tank, San Francisco volcanic field, northern Arizona. In Karlstrom, K. E., ed. Proterozoic geology and ore deposits of Arizona, Ariz. Geol. Society. Digest 19: 153-163.

Nealey, L. D.; Unruh, D. M.; and Maldonado, F. 1993. Sr$\mathrm{Nd}-\mathrm{Pb}$ isotopic maps of the Panguitch $1: 100,000$ quadrangle. U.S. Geol. Surv. Open File Rep. 93-691, scale, $1: 250,000$.

Noorish, K., and Hutton, J. T. 1969. An accurate X-ray spectrographic method for the analysis of a wide range of geological samples. Geochim. Cosmochim. Acta 33: 431-453.

Ormerod, D. S.; Rodgers, N. W.; and Hawkesworth, C. J. 1991. Melting in the lithospheric mantle: inverse modeling of alkali-olivine basalts from the Big Pine Volcanic Field, California. Contrib. Mineral. Petrol. 108:305-317.

Perry, F. V.; Baldridge, W. S.; and DePaolo, D. J. 1987. Role of asthenosphere and lithosphere in the genesis of Late Cenozoic basaltic rocks from the Rio Grande rift and adjacent regions of the southwestern United States. J. Geophys. Res. 92:9193-9213.

Perry, F. V., and Straub, K. T. 1996. Geochemistry of the Lathrop Wells volcanic center. Los Alamos Laboratory Report LA-13113-MS, 10 p.

Reid, M. R., and Graham, D. W. 1996. Resolving lithospheric and sub-lithospheric contributions to helium isotope variations in basalts from the southwestern U.S. Earth Planet. Sci. Lett. 144:213-222.

Reid, M. R., and Ramos, F. C. 1996. Chemical dynamics of enriched mantle in the southwestern United States: thorium isotope evidence. Earth Planet. Sci. Lett. 138: 67-81.

Rodgers, N. W.; Hawkesworth, C. J.; and Ormerod, D. S. 1995. Late Cenozoic basaltic magmatism in the Western Great Basin, California and Nevada. J. Geophys. Res. 100:10,287-10,301.

Unruh, D. M.; Nealey, L. D.; Maldonado, F.; and Nusbaum, R. 1994. Sr-Nd-Pb isotopic maps of late Cenozoic volcanic rocks of the St. George 30' $\times 60^{\prime}$ quadrangle, southwestern Utah. U.S. Geol. Surv. Open File Rep. 94-11.

Wenrich, K. J.; Billingsley, G. H.; and Blackerby, B. A. 1995. Spatial migration and compositional changes of Miocene-Quaternary magmatism in the western Grand Canyon. J. Geophys. Res. 100:10,417-10,440.

Wilcox, R. E. 1954. Petrology of Parícutin volcano, Mexico. U.S. Geol. Surv. Bull. 965C:281-353.

Wilson, M. B. 1989. Igneous petrogenesis. London, Unwin Hyman, 466 p.

Wooden, J. L., and DeWitt, E. 1991. Pb isotopic evidence for the boundary between the Early Proterozoic Mojave and Central Arizona crustal provinces in western Arizona. In Karlstrom, K. E., ed. Proterozoic geology and ore deposits of Arizona. Ariz. Geol. Soc. Digest 19:27-50.

Wooden, J. L., and Miller, D. M. 1990. Chronologic and isotopic framework for early Proterozoic crustal evolution in the eastern Mojave Desert region, SE California. J. Geophys. Res. 95:20,133-20,146.

Yogodzinski, G. M.; Naumann, T. R.; Smith, E. I.; Bradshaw, T. K.; and Walker, J. D. 1996. Evolution of a mafic volcanic field in the central Great Basin, southcentral Nevada. J. Geophys. Res.101:17,425-17,445. 